\title{
Zhongnan Temple Fair: Human Resources and the Value of Art Education from the Perspective of Cultural Space
}

\author{
Tu Jun \\ Associate Professor, School of art, Xi'an University
}

Keywords: Cultural space, Zhongnan temple fair, Cultural resources, Art education

\begin{abstract}
Through the investigation of the rich and colorful life style and the spiritual and cultural elements contained in the temple fair in the Mountain Zhongnan area, the relationship between cultural space and the cultural resources of the temple fair is combed, and the important role in shaping the local cultural heritage system is discussed. The paper also analyzed the location spirit, space distribution and resource distribution of temple fair culture in the Mountain Zhongnan area. It is concluded that the cultural resources of the Zhongnan temple fair is an important part of the cultural space of intangible cultural heritage and it should be deeply excavated and protected. The inheritance of the temple fair is the identity of the Chinese excellent traditional culture. In the art education, we should emphasize the local cultural foundation and national psychology, and explore the value and significance of art education in temple fair culture.

Cultural space, which is also called "cultural sites", refers to a place where the popular traditional cultural activities are centrally held, or a period time of regular activities ${ }^{[1]}$, with both time and space. Cultural space can condense the traditional cultural elements in a specific time and space. The temple fair and its place is a collection of people's ideological activities and behavioral activities in this particular time and space.
\end{abstract}

\section{Cultural Space and Cultural Resources of Temple Fair}

"Cultural space" is a place where a popular traditional cultural activity is held, or a period of time that is usually scheduled for a specific activity ${ }^{[2]}$. Cultural space has the characteristics of being alive, certain cycle and time, and closely related to people's life style. From the angle of culture, cultural space is analyzed with cultural attributes. Cultural space is closely related to people's life form, that is, various forms of folk art and ceremonial activities.

\section{Resources Reserve of the Zhongnan Temple Fair}

Zhongnan Mountain usually refers to the middle part of the Qinling Mountains, west from Mei County of Baoji, and east to Lantian County, Xi'an. The main peak is located at the junction of Zhouzhi County and Taibai County. From the ancient time, the Taoist temple, the relevant temple fairs spread along with the geographical distribution of the temples. In the area of Zhongnan Mountain, there are 7 temple fairs in Lantian, 40 in Zhouzhi and Taibai, 43 in Changan, 27 in Huyi[3]. These places hold at least one big temple fair each year. The famous temples have at least three big temple fairs each year. And there are small religious activities at the beginning and fifteenth day each month. According to the survey of 1987, "only 1042 natural villages in Zhouzhi County , 782 of which held temple fairs; 29 temple fairs have more than 10 thousand people, and more than 100 temple fairs have over 5000 people"[4]. Thus, the environmental space of the religious temple is the important space for the temple fairs.

\section{Cultural effects of famous Buddhist Mountains}

The Buddhist resources of Zhongnan Mountain include 5 ancestral Buddhist temples, Kwan-yin Buddhist sanctum in Nanwutai and famous Buddhist temples in Jiawutai. From Zhouzhi to the west of Baoji, is the west section, there are Jiulin temple groups in ancient times; Huyi and Changan is the middle section, most Buddhist temples are in this area. In Huyi County there is Baolin Temple in Zige Valley, the Ming Yang Temple in the Li Valley, the Xinlin temple of Zhi Valley, and so on. In Changan County, there are Jinye Temple, Fengde Temple, Guanyin Temple, Wofo temple in 
Feng Valley, Tianchi Temple in Jiao Valley, Xingqin Temple and Xinan Temple in Jiawutai Mountain, Temple of Lianhua Cave in Dayu Valley, etc. The section of Lantian is the east section. There are more than 30 temples including the famous temples such as Shui Lu nunnery, Wu Zhen temple. The history of these temples can be traced back to thousands of years, some of which have the background of the Royal monasteries in the Sui and Tang Dynasties; some are from the private house of noble families. And each temple has an endless historical story. As a saying "The Monks occupy much of the famous mountains", the religious atmosphere in the Zhongnan Maintain attracts numerous hermits. The unique landscape of Zen environment has formed a favorable atmosphere for people to practice. The religious environment has better spread the philosophical thought of Buddhism. Buddhism has great influence on Chinese traditional ethical and moral concepts. The thought of good and evil has promoted the stability of society, and "Be happy to give and do well" has strengthened the social atmosphere of kindness and friendliness of the Chinese people. Therefore, the religious culture of the Zhongnan Mountain has a profound influence.

\section{The brand effect of Taoist shrines}

Zhongnan Mountain is also a sacred place of Taoist culture, and the Lou Guan School and Quan Zhen Taoism were born here. The Louguantai temple which was first built in the Western Zhou Dynasty and the Chung Yang palace, which was founded in the song and Yuan Dynasties, are respectively called the first of the seventy-two blessed Taoists and the first of the three great ancestral temple of the Quan Zhen School. Therefore, Taoism took this place as their origin; they search human nature and life value while regulating people's moral concepts and social norm. The Taoism takes this place as blessed spot, where Taoists obtain excellent practice. The ancestors' worship for the sun, the moon, the stars, mountains and rivers become a part of the Taoist cosmology, of which the birthday of the important gods became the festivals of the folk temple. Taoism advocates ecological philosophy of natural inaction, adaptation to heaven, harmony between man and nature, the ecological philosophy of harmony helps people to actively understand the way of existence. .

\section{The commercial effect of the temple fair}

The Temple fairs are mostly held during slack season or busy gap. According to the length of time, there are large, medium and small scale temples fair. The number of people will be directly proportional to commodity transactions. In the economically underdeveloped rural areas, there is a lack of production and living materials. When there are large temple fairs, people will concentrate on purchasing, so the turnover is large.

In Huyi part, the famous temple fairs in Zhongnan are the Huayang Temple fair in Feb.1, and June 15, the Lou Jing Temple fair in Feb.25, Qingliang Temple fair in Jan. 9, Chong Yang Palace Temple fair in Sept. 9, and temple fair in Jiuhua Mountain in March 18. In Huayang temple fair, believers from nearby counties and counties north of Wei River also attend the temple fair. Gan River is the temple fair for Dongyu temple, it is also called Lantern temple fair, because it is held between the Spring Festival and The Lantern Festival. In the county town, the City God temple fair is held in Aug. 2.Every year on the 15th day of the tenth month of the Chinese lunar calendar, there will be an "October meeting" competition. "Competition, luxurious magnificent" [5].

In Chang An County there are the ancient Temple fair in Mar. 5, Cao Fang temple fair in Dec. 8, Weiqu Luoma temple fair in March, Guodu Luoma temple fair in Oct. 7,

Jiangcun temple fair in Feb. 15, Liang Jia Qiao temple fair in Feb. 2, Nanwutai temple fair in June 1, Wang Qu City God temple fair in Feb.8, and the Louguantai Temple fair in Feb. There are 30-40 temple fairs in Zhouzhi and Taibai ${ }^{6]}$.

In Lantian, there is Xishui Cave temple fair in early Feb., Shui Lu An temple fair in Jan. 25. According to the three day statistics in 1989, more than 100 thousand people attended the temple fair of $\mathrm{Wu}$ Zhen temple fair and Shui Lu An temple fair ${ }^{[7]}$.

In the villages, people of several villages hold temple fair together. for example, the City God temple fair in the north of Huyi County, the big city god collect 19 villages, the second City God collect 21 villages, the third City God collect 13 villages. They held the temple fair in turn. In this way, the scale of the temple fair become larger, which may attracts more businessmen and 
consumer.

The Temple fair is an important medium for farmers to purchase farm implements and daily necessities, and religious form is just an opportunity to carry out product transactions. For example, in the Louguantai temple fair in Feb.2, 80\% of the farmers in the East Louguan Village are engaged in the catering service. The number of participants reached one hundred thousand people, and the purchasing power was very strong. In an early (1990) record of the temple fair in Zhou Zhi, they had 48 play shows during the temple fair, and the performance cost about 1200000 Yuan including traffic and lodging. Both consumption and expenditure come from the commercial effects of temple fairs, which affect businessmen in nearby counties, and even provinces and cities.

\section{The Distribution Environment of the Zhongnan Temple Fairs}

Based on the above analysis of the resources of Zhongnan Buddhist temple buildings, Taoist temples, and religious mountains, the distribution environment of the Zhongnan temple fairs can be divided into three types: Plains, mountains and adjacent waters. According to data collection, the Zhongnan temple fairs are dominated by mountain temple fairs and plains temple fairs.

\section{The environmental space of the plain Temple Fair}

The plain temple fair is depend on the building environment of the temple in the village, and is interlaced with the folk houses. It is limited by the traffic, the community environment, the flow of people and so on. Some temple fairs are gradually reduced in scale and the number of times because of the undesirable geographical position, the large flow of people, and some temple fairs are chased by the businessmen and consumers for the advantages of the traffic convenience, which become large entertainment temples. Most of the temple fairs in the rural areas use the farmland as place for temple fairs, most of which do not have a fixed temple space.

\section{The environmental space of the mountain temple fair}

The environmental space of the mountain temple fair is determined according to the site selection of temple buildings. There are large mountain temple fairs based on mountain forests. In combination with topographic and geomorphic features, the site will consider a few factors such as leeward, rainwater, water source and forest. The common form is the form of "mountain tail", "two wings encircling" and "tail Bag Mountain"[8]. The first type is the Temple hidden in the mountain forest and more open space in front of the temple, it is not easy to hold large temple fairs; the second type is the mountain peak behind the temple, the side ridge with two wings, the environment is open, the temple space is suitable for the view. It is easy to form a temple fair group; the third type is to use the hillside slope land, the temple buildings are built along the slope, the sightseeing is limited, and the related recreational activities can be extended to nearby plains. And it attracts more people.

\section{The environmental space of water adjacent temple fair}

Water adjacent type starts with the landscape environment of river, lake and sea. Combining with the nearby mountains, the environment is like a garden. The garden environment not only makes religious etiquette more sacred, but also enables temple fair activities to have both sightseeing functions. The gardening process of the temple is an opportunity for the development of the water adjacent temple fairs. By adding gardening area in temple or building a subsidiary garden beside the temple, the temple is transferred from the external environment to the natural landscape, and integrates itself into the landscape. The gardening environment can make religious etiquette more sacred, and the garden space also enables temple fair activities to have sightseeing functions. The combination of natural landscape and temple architecture expands the activity space of temple fairs.

\section{The Place Spirit of the Zhongnan Temple Fair}

The Zhongnan Mountain has having a mysterious religious atmosphere since ancient times. The temple fair is a rich intangible cultural heritage, the fixed cultural place formed by the temple fair and the spontaneous cultural space become the main carrier of the non material culture, and the 
relationship of each cultural element in the cultural system is different, forming the different forms of the cultural space of the Zhongnan temple fair. The form of temple fair activities carries the life interest of people in the farming age, forming stable exchange of time and space between material and non-material culture, relying on the expression of art in the space. It has the spirit of regional culture and contains the contents of religious belief.

\section{The home of the soul}

The religious ceremony of the temple fair has a subtle influence on people's psychology, including the attitude of the people to God, the balance in the worship of God and the pan God, the realization of comfort and redemption in the praying and seeking ceremony, the release of spirit in the act of view and leisure, and the realization of spiritual sublimation in the act of giving and giving up, realizing the purpose of religious remedies and charities.

\section{The spirit of the Carnival}

Temple fair activities focus on the humanistic care and entertainment nature, weaken the seriousness of religion in form, and making the secular life people oriented. With the help of entertaining gods show, the purpose of universal carnival is achieved. In fact, it is a manifestation of being close to the people, enabling to harmonize the relationship between neighbors through entertainments. For example, Jixian ancient music in Zhouzhi, shadow play, puppet play, and Shehuo performance during the Spring Festival is a way of expressing folk celebration. Through the religious and activity ritual, the confidence and strength of the body are given to conquer fear and realize self value, so as to achieve the orderly development of society.

The place spirit of temple fair is the precondition for people to get the sense of inheritance and belonging, and also the foundation of the temple fair. The form of temple fair activities carries the life interest of people in the farming age, forms a stable space and time communication between material and non material culture. Relying on artistic expression in the site space, it has the spirit of regional culture and contains the contents of religious belief.

\section{The Value and Significance of Temple Fair to Art Education}

At present, there are some deficiencies in the cultural philosophy of contemporary college education. From the perspective of art and education, there are some disadvantages, such as the narrowing of the goal, the tendency of utility in education, and so on [9]. Through the study of temple fair culture, the regional environment, and humanistic space spirit, some thoughts on the current art education have been put forward.

The first is the return of the humanistic value. The creation of religious belief has gone through the worship of various gods from ancient times, from totem worship, nature worship to reproduction worship, from the norms of the Confucian etiquette, the creation and development of Taoism, and the spread and popularization of Buddhism, which jointly constructed a cultural circle of regional belief and played an important spiritual guiding role in the secular activities. It affects the emergence and development of folklore activities. At the same time, the secular culture, with its emphasis on humanistic care and entertainment, has weakened the seriousness of religion in form and made the secular life to be people-oriented.

For the art education in Colleges, the experience and feeling of this kind of humanistic spirit is a rare artistic atmosphere. It not only explores artistic conception of artistic creation, but also draws the true meaning of life from the spirit of scene, tastes the truth, goodness and beauty of life, improves the spiritual realm of art practice and creation.

The second is the shaping of national self-confidence. The influence of temple fair culture is immeasurable to the region, and it bears the role of cultural popularization and cultural dissemination. In the form of the temple architecture, the religious ceremony of the temple fair and performances for entertaining Gods, the spiritual consciousness of people's thought, morality and the praying for life are reflected. All kinds of cultural phenomena appearing in temple fairs are radiating around the temple as the axis field, playing the role of cultural transmission. In these activities, people find self-confidence in national culture. A variety of resources in temple culture space enable art education to gain a sense of field teaching, forming a sense of identity of folk 
culture and the sense of mission of folk culture inheritance. The value of education is also reflected.

To sum up, through the analysis of the distribution of cultural resources, the type of space distribution and the spirit of the place of the Zhongnan temple fair, it can be seen that the environment of the Zhongnan temple is the important landscape resource and activity place of the temple fair. The site environment of the temple determines the expansion type of the temple fair space, and the temple's own environmental advantages can improve the fame of the temple fair. It also changes the functional space of temple fair and expands the scale of temple space. The relationship between the temple fair and the environment is mutual influence and contributes to the resource network, and the environment is the prerequisite for the building of temples. The temple fair is the main factor of the temple environment becoming the local cultural resources. The study of the resources advantage of the cultural space of the Zhongnan temple fair is to promote the cultural development of the region and promote the cultural and economic development of local tourism on the basis of cultural application and practice. At the same time, it is also a reflection of the promotion of the ideas and values of art education.

\section{Acknowledgements}

Supported by Shaanxi Educational Committee special scientific research project (Fund No.14JK2133) And Supported by Xi'an Social Science Planning Project (Fund No.15WL23)

\section{Reference}

[1][2] Wang Wenzhang, an outline of intangible cultural heritage, Beijing: culture and Art Publishing House, 2006.10:296

[3] According to the data of Huxian County Annals, Zhouzhi County Annals and Changan County Annals

[4][6] Zhouzhi County Annals compiling committee, Zhouzhi County Annals, Xi'an: Sanqin Publishing House, 1993.08:486, 489

[5] Huxian County Annals Compilation Committee, Huxian County Annals, Xi'an MapPublishing House, 1987:04:520

[7] Lantian County Annals Compilation Committee, Lantian County Annals, Shaanxi People's Publishing House, 1994.07:619

[8] Xin Jianrong, Tourism area planning and management. Nankai University Press, 1999.05:220-221

[9] Li Jinsong and Jiao Jiejie, Cultural philosophy: the goal orientation and value appeal of art education in Colleges, 2018.2:22-26, Jiangsu Higher Education 